\title{
84
}

Rupantaran : A Multidisciplinary Journal

Vol. III : 84-92, March, 2020

ISSN : 2091-0061

Research Management Cell (RMC)

Dhankuta Multiple Campus, Dhankuta

Tribhuvan University, Nepal

\section{Curricular Issues in School Education: Critical Analysis of Understanding about the Implemented Curriculum}

\author{
Nirmal Raj Mishra ${ }^{1}$ \\ Email:nirmaltu@gmail.com
}

\begin{abstract}
This paper focus on exploring the curricular issues viz. subject matter, pedagogy and assessment process of implemented/taught curriculum in school education. Similarly, the teachers'understandings are key areas to find out the issues in education that are guiding engine to operate schools' education efficiently. During this study course, it adopted the descriptive as well as phenomenological methodology on the basis of educational literature, own experience and group discussion with selected teachers. The dilemma about curricular components has created the new discourse in school education today. Moreover, the challenges to improve the elaborated isueses are crucial problems for teachers in enhancing quality teaching learning skills.
\end{abstract}

Key Words: philosophical roots, implemented curriculum, subject matter, pedagogy and assessment process

\section{Introduction}

This section has included the philosophical perspective about curriculum and concept of curriculum from different educational philosophy. This clears the general philosophical background and context of this research article's problem.

\section{Philosophical perspective about curriculum}

The perennailists and essentialists education philosopher advocated the curriculum as the subject matter and they highly advocated that knowledge is the prime aspects of curriculum elements. This side of philosophers only see the intellectual aspects of human being rather than physical, social and emotional aspects (Ornstein and Hunkins, 2018; Tanner and Tanner, 1990). Their claim is that the specialized knowledge can only help to adjust in day to day life. Similarly, the perennailism and essentialism focused on classical analysis, literary analysis, constant curriculum and

1. Mr. Mishra is a lecturer of curriculum and evaluation at Tribhuvan University, Dhankuta Multiple Campus, Dhankuta. 
three Rs (reading, writing and arithmetic), essential subjects like English, science, history, math and foreign language respectively (Ornstein and Hunkins, 2018). In another side, John Dewey, William Kilpatrick advocated the experience centered curriculum that focused on the learners' autonomy, needs and interests. They have the focus on the project method and problem solving method for effective teaching. This group of educational philosophers emphasized on the child centered curriculum where established the concept of curriculum as experiences, guided living, and extra class activities (Tanner and Tanner, 1980). Similarly, progressivism believed and advocated the issues of student's interests and child centered pedagogy related issues and promoted the curriculum trend like humanistic education (Ornstein and Hunkins, 2018).

These four educational philosophies created the different discourse in implemented curriculum and prioritize different curricular issues in education. In such way, these philosophies focused on the different new trends in education in different era. The curriculum related issues and trends highlights in such way.

Table 1: Curricular issues and trends

\begin{tabular}{|l|l|l|l|}
\hline \multicolumn{1}{|c|}{$\begin{array}{c}\text { Educational } \\
\text { philosophy }\end{array}$} & \multicolumn{1}{|c|}{$\begin{array}{c}\text { Philosophical } \\
\text { base }\end{array}$} & Curricular issues & \multicolumn{1}{c|}{$\begin{array}{c}\text { Related } \\
\text { curriculum trends }\end{array}$} \\
\hline Perennailism & Realism & $\begin{array}{l}\text { Classical subjects } \\
\text { and Constant } \\
\text { subject matter } \\
\text { related issues }\end{array}$ & $\begin{array}{l}\text { Great books } \\
\text { Returning to the } \\
\text { liberal arts }\end{array}$ \\
\hline Essentialism & $\begin{array}{l}\text { Idealism and } \\
\text { realism }\end{array}$ & $\begin{array}{l}\text { Essential skills } \\
\text { (3Rs) } \\
\text { Essential subject } \\
\text { matter related issues }\end{array}$ & $\begin{array}{l}\text { Back to basics } \\
\text { Cultural literacy } \\
\text { Excellence in } \\
\text { education }\end{array}$ \\
\hline Progressivism & Pragmatism & $\begin{array}{l}\text { Student's interests, } \\
\text { needs and human } \\
\text { problems and affairs } \\
\text { and child centered } \\
\text { pedagogy related } \\
\text { issues }\end{array}$ & $\begin{array}{l}\text { Relevant } \\
\text { curriculum } \\
\text { Humanistic } \\
\text { education } \\
\text { Radical school } \\
\text { reform }\end{array}$ \\
\hline Reconstructionism & Pragmatism & $\begin{array}{l}\text { Social, economic } \\
\text { and political } \\
\text { problems and } \\
\text { present and future } \\
\text { trends related issues }\end{array}$ & $\begin{array}{l}\text { International } \\
\text { education } \\
\text { Equity in } \\
\text { educational } \\
\text { opportunity }\end{array}$ \\
\hline
\end{tabular}


The modernism raised voice about individual freedom, freedom to expression, and technocratic thinking in education and curriculum. In contrary, the postmodernist philosophers raised the issues of equity and social justice of learning through curriculum. They promoted the multicultural knowledge construction process and equity pedagogy in classroom teaching (Ornstein and Levin, 2008).

\section{Summary of concept of curriculum from different educational philosophy}

The concept of curriculum emerged from the different philosophical assumptions and focused on the different areas of knowledge that is depicted in the following Table.

Table 2: Concept of curriculum from different educational philosophy

\begin{tabular}{|l|l|l|}
\hline Educational philosophy & \multicolumn{1}{|c|}{ Concept of curriculum } & \multicolumn{1}{|c|}{ Main emphasis } \\
\hline Perennailism & Curriculum as subject matter & Permanent knowledge \\
\hline Essentialism & Curriculum as subject matter & Essential knowledge \\
\hline Progressivism & Curriculum as experience & $\begin{array}{l}\text { Learners needs and } \\
\text { interests }\end{array}$ \\
\hline Reconstructivism & Curriculum as social reform & $\begin{array}{l}\text { Social problems and } \\
\text { affairs }\end{array}$ \\
\hline Modernism & Curriculum as plan & $\begin{array}{l}\text { Scientific innovation } \\
\text { and experiment }\end{array}$ \\
\hline Postmodernism & $\begin{array}{l}\text { Curriculum as cultural } \\
\text { promotion }\end{array}$ & $\begin{array}{l}\text { Local belief and } \\
\text { contextual wisdom }\end{array}$ \\
\hline
\end{tabular}

Sources: Taba, 1962; Print, 1993; Bhalla, Ornstein and Hunkins, 2018; Tanner and Tanner, 1980 and Ornstein and Levin, 2008

\section{Areas of curriculum emphasis}

The concept of curriculum is specified according to the areas of curriculum emphasis. The subject specialists, teachers, and learners understand about the curriculum differently such as intended, implemented, and learned curriculum.

The intended curriculum refers to curriculum framework, guidelines and standards that are outline to the teachers for delivery (Porter \& Smithson, 2001). This type of curriculum focuses on what should be taught by the teachers in the educational system (Print, 1993). It is a map of theories, beliefs and intentions of schooling, teaching and learning (Cuban, 1992). Similarly, it is influenced and regulated by the school authorities, powerful and external forces like government, religious order, pressure groups etc. (Billett, 2006).

The taught curriculum also known as implemented and enacted curriculum. This is the practical and action oriented process of curriculum where various teaching 
learning activities conducted on the basis of intended curriculum (Billett, 2006). Similarly, it is also called the delivered curriculum and can be seen an action where teacher teaches. It refers to the actual curricular contents that student engage in the classroom (Porter \& Smithson, 2001). Furthermore, the implemented curriculum focuses on what is actually taught by teachers in their classroom where students interact with the intended curriculum (Print, 1993).

The learned curriculum also known as achieved curriculum. It denotes the changes in values, belief, perceptions and behavior in students. It is the product of intended and taught curriculum (Porter \& Smithson, 2001). Similarly, it refers to that the students actually learnt as a result of interaction with implemented curriculum in instructional setting (Print, 1993).

\section{Methods and Materials}

The main purpose of this paper is to analyze the curricular issues in terms of subject matter, pedagogy and assessment process. For this purpose, this study has been conducted on the basis of qualitative research design where the descriptive as well as phenomenology methodology used to operate the research activities (Creswell, 2007). For collecting the data, the secondary level ten teachers were purposively selected those who have at least fifteen years' experiences. The information collection method like focus group discussion has been conducted to the selected teachers. Furthermore, the information has also been collected through curriculum related literature and researcher's introspection. After collecting the information, the thematic analysis has been used where the problem base themes were generated and analyzed separately (Patton, 2002).

\section{Results and Discussions}

The curriculum helps to promote the teaching learning and boost up instructional activities. It helps to guide the teachers for making learning more systematic, flexible and precise. In the substantive nature of curriculum, there are various viewpoints which changes periodically. Now a day, it has roughly practices that knowledge accumulation is the sole understanding of curriculum in our education system. This type of understanding promotes the mind-pocket system of knowledge where students must be stored the information in mind as a worry matters. Similarly, it has also established that knowledge is essential for obtaining high marks in exams where not focused on skills, process and attachment of living. Moreover, there are various perceptual understanding about curriculum which have been created the discourses in teaching and learning. The curricular issues in subject matter, pedagogy and assessment process have been discussed and analyzed separately. 


\section{Subject matter issues}

According to Bloom's taxonomy, subject matter/content must cover the three domain of knowledge like cognitive, affective and psychomotor. Similarly, Morzano and Kendal (2007) presented the information, mental procedural and psychomotor procedural knowledge that covers the various types of knowledge through the objective formulation during curriculum development process. The subject matter related advocators focused on the facts, principles, generalization for mental/intellectual development of learners. The educational philosophy like perennailism and essentialism highly focused on the subject matter and perceives curriculum as subject matter or list of content (Ornstein and Hunkins, 2018). In contrary, Tyler (1949) did not focus on the subject matter as a curriculum element. He has emphasized on the learning experiences as a curriculum element. Similarly, pragmatics educationists also emphasized on the learning experiences of learners in place of content.

On the basis of subject matter related issue, it was found that teachers highly emphasized on the content and they believed in knowledge as only sole area to enhance the student performance. They only prefer the content and practice mental dedication for knowledge storage in mind. What to teach? is the prime question for teaching and not focused on procedural knowledge, skills and values. One of the teacher said that knowledge or subject matter is the key component of curriculum and should be focused on this element to achieve the better performance in exam. It cleared that the knowledge base instructional activities primarily emphasized by the teacher in school. Similarly, they have focused on the textbooks for implementing the intended part of curriculum. This discussion helps to reach the conclusion that this is the era of knowledge domination for intellectual development of learners in Nepal. But another side, the social, emotional and spiritual development of learners has been in shadow of our education system.

\section{Pedagogical issues}

Teacher centered pedagogy vs student centered pedagogy is a crucial issue in student teaching. Philosophical world view also opens the door for this debate whereas perennailism and essentialism focused on the teacher centered pedagogy and progressivism and reconstructinism advocated the student centered pedagogy. Similarly, constructivism also promoted the learning by doing and problem base learning (Ornstein and Hunkins, 2018; Ornstein and Levin, 2008). Furthermore, the learner centered pedagogy helps to students for active involvement in knowledge construction process rather than mere passive listeners. The constructivist instructional model promotes the active involvement of learners, democratic environment for learning and facilitates the interactive activities (Thakur, 2014). Nowadays, the educationist believed that the diversified child centered activities helps to promote 
the students' achievement. According to Banks (2006) "multicultural approaches of teaching and learning help to students learn how to function more effectively within their own community culture, within other cultural communities, within the national and global communities" (p. 121). Likewise, the terms like define, classify, guess and construct should be used in teaching learning activities that facilitate the students' progress. The teaching learning activities should promote the multiple opinions and encourage the students to put their opinions, feelings and values. The learner autonomy and interactive relation with students is necessary for effective teaching where the teaching strategies like problem based learning, case studies, project based learning and collaborative learning must be used in teaching learning activities (Karadumam, 2007). Moreover, reciprocal teaching allows for the creation of a dialogue between students and teachers. This two-way communication becomes an instructional strategy by encouraging students to go beyond answering questions and engage in the discourse (Driscoll, 1994).

In my introspection and field experiences, it was found that teachers were highly aware to use the student centered and interactive teaching pedagogy. One of the teachers told that classroom activities must be based on the students' needs and interests. He also added that the interactive classroom environment can only solve the diversified needs of students. Another teacher claimed that the project method and collaborative method helps in developing creative and higher order thinking in students. In another side, the school curriculum highly emphasized on the learner centered methods like project method, inquiry method, discovery method etc. But on contrary, teachers have been habituated in lecture method for delivery of content. Moreover, they used the demonstration and discussion methods as per the need of lesson structure. According to them, they used the most common methods like lecturer, demonstration, discussion and question answer in delivery process. They also used the lecturer with illustration through the multimedia projector. With the help of this discussion and my reflection, I concluded that teachers have taken learner centered and interactive activities as a burry task apart from the lecture method and note writing practices. And it has cleared that there is a huge gap between teachers' perception and pedagogical practices in the classroom.

\section{Assessment issues}

Assessment is a part of teaching learning process which helps to increase the students' performance. It is also part of curriculum elements that judge the effectiveness of expected learning outcome on the basis of intended curriculum. Furthermore, assessment can be used the purpose like formative as well as summative. The assessment related issues has been entered as a burning issues in todays' instructional activities. 
In our school education, the both purposes expect to address during the instructional activities. But, teachers have perceived the assessment process as to judge the effectiveness of students' performance only. They believed that it is necessary to justify the students' achievement. Similarly, they have used the written test for students' assessment in terms of first terminal, second terminal and final exam. The home work, class test and unit test also used to prepare for the terminal exam. The one teachers believed, it is a continuous process that helps to improve the students' achievement. Furthermore, he added that it helps to overcome the learning difficulties and motivate/encourage to the students in learning. The new trends of assessment like performance base assessment and portfolio recording have not been practiced according to the rules and expectations of curriculum. The teachers have not been aware the alternative assessment tools like interview, check list, rating scale, portfolio record, interpretive exercise and open library test. They believed that the written test can only measure the students' achievements more reliable and valid way. In another side, they have lot of knowledge about the tools like portfolio record, rating scale and check list. But they are reluctant to use these tools because they have felt as a burden tasks for implementation and scoring of students' assessments.

Due to these facts, it was found that the test base assessment practice has been established deeply in our school education. In recent year, the standardized and teacher made test based assessment practice have been transforming into the open library test and digital examinations.

\section{Conclusions}

The implementation of curriculum is a crucial aspect in behavior modification of students. The intended curriculum provides the detail plan which have to solve the questions like a) what to teach? b) why to teach? c) when to teach? and d) what is the impact of teaching (Print, 1993). This form of curriculum has covered wider area than implemented and learned curriculum. The implemented curriculum is a practical and interactive aspects where various teaching learning activities are conducted in classrooms. The effectiveness of intended curriculum depends on the implemented curriculum. So, this paper concluded that there is a vast gap between the intended and implemented curriculum. The gaps should be minimized for improvement of students' achievement. Without the effective delivery of content, we cannot expect the better achievements. Similarly, the success and failure of implemented curriculum depends on the content delivery process, pedagogical practices and assessment process during the teaching learning activities. These types of activities have been directly seen in the learned curriculum which reflects the effectiveness of implemented curriculum. Last but not least, the curriculum implementation personal must be devoted for implementing the curriculum according to the curricular intents. 


\section{References}

Banks, J. A. (2006). Cultural diversity and education. New York: Pearson.

Best, J. W. \& Kahn, J. V. (2006). Research in education. New Delhi: PHI learning Pvt. Ltd.

Billett, S. (2006). Constituting the workplace curriculum. Journal of Curriculum Studies. Vol. 38 (1) pp 31-48. doi: 10.1080/00220270500153781

Bloom, B. S. (1956). Taxonomy of educational objectives: the classification of educational goals. Handbook I: cognitive domain. New York: David Mckay.

Creswell, J. W. (2007). Qualitative inquiry and research design: choosing among five approaches. New Delhi: Sage publication.

Cuban, L. (1992). Curriculum stability and change. In P. W. Jackson (Ed.), Handbook of research on curriculum (pp. 216-247). New York: Macmillan Publishing Company.

Driscoll, M. P. (1994). Psychology of Learning for Instruction. Needham, Ma: Allyn \& Bacon.

Erkilic, T. A. (2008). Importance of educational philosophy in teacher training for educational sustainable development. Middle East Journal of Scientific Research. Vol.3(1) 01-08.

Karaduman, H. A. (July 2007). The effect of constructivist learning principles based learning materials to students' attitudes, success and retention social studies. The Turkish online journal of educational technology-TOJET, 6 (3), 98-112.

Morzano, R. M. \& Kendal J. S. (2007). New taxonomy of educational objectives. California: Corwin Press.

Ornstein, A. C. \& Hunkins, F. P. (2018). Curriculum: Foundations, principles and issues. New York: Pearson Education Ltd.

Ornstein, A.C. \& Levine, D.U. (2008). Foundations of education. Boston Newyork: Library of Congress.

Patton, M. Q. (2002). Qualitative research and evaluation design. Thousand Oaks, California: Sage Publication.

Porter, A. C. \& Smithson, J. L. (2001). Defining, developing and using curriculum indicators. CPRER Research reports. Retrieved fromhttp://repository.upenn. edu/cpre_researchreports/69.

Print, M. (1993). Curriculum development and design. Australia: Allen \& Unwin.

Taba, H. (1962). Curriculum development: theory and practice. USA: Harcourt, Brace \& World Inc.

Tanner, D. \& Tanner, L. N. (1980). Curriculum development: theory and practice. New York: Macmillan Publishing Co, Inc. 
Thakur, K. (2014). A constructivist perspective on teaching and learning: a conceptual framework. International research journal of social sciences. 3(1), 27-29.

Tyler, R. W. (1949). Basic principles of curriculum and instruction. Chicago: University of Chicago Press. 